mgr. inz. Maciej Nowak

dr hab. inz. Piotr Krawiec prof. PP

Politechnika Poznańska

\title{
System pozycjonowania baterii fotowoltaicznych
}

\begin{abstract}
$W$ artykule przedstawiono koncepcje automatycznego układu nadażnego umożliwiajacego pozycjonowanie baterii fotogalwanicznych względem stońca. Położenie ziemi wobec stońca jest zmienne i zależne od pory roku oraz dnia. W celu absorpcji jak największej części energii emitowanej przez stońce, konieczne jest zastosowanie aktywnego systemu śledzenia. Przedstawione $w$ artykule rozwiazanie ma na celu podniesienie wydajności baterii fotowoltaicznych lub kolektorów stonecznych. W pracy wskazano przyklady $i$ możliwości zastosowania baterii stonecznych w pojazdach szynowych.
\end{abstract}

\section{Wstęp}

Prognozy dostępności klasycznych nośników energii wskazują, że zasoby węgla kamiennego wyczerpią się za około 40 lat, węgla brunatnego za 200 lat, ropy naftowej za 25 lat, a gazu ziemnego za 30 lat [1]. Wykorzystanie wymienionych źródeł energii generuje ponadto ogromne zanieczyszczenia do atmosfery, co w związku z podpisanym przez Polskę pakietem klimatycznym zakładającym redukcję gazów do roku 2020 o 30\% staje się ogromnym problemem finansowym.

Niezbędne staje się, więc rozwijanie metod pozyskiwania nowych źródeł energii takich jak: elektrownie wodne, wiatrowe, energia słoneczna. Aktualnie bardzo rozpowszechnione jest pozyskiwanie energii słonecznej za pomoca ogniw fotowoltaicznych. Jest to szczególnie uzasadnione w krajach bardzo i średnio nasłonecznionych, a nieposiadających klasycznych nośników energii.

Energię słoneczną cechuje ekologiczność, bezpieczeństwo, a jej złoża sa „niewyczerpane”. Przewiduje się, że „śmierć słońca" nastapi za około 5 miliardów lat. Wykorzystanie energii promieniowania słonecznego wymaga zastosowania stosunkowo niedrogich układów fotogalwanicznych przekształcających energię słoneczną na prąd elektryczny. Dzięki zastosowaniu kolektorów słonecznych możliwe jest magazynowanie energii elektrycznej i wykorzystanie jej np. w nocy. Położenie ziemi względem słońca podlega zmianom dobowym i rocznym, dlatego niezbędne jest stosowanie układów nadążnych umożliwiających automatyczna zmianę położenia paneli fotogalwanicznych względem słońca (rys. 1).

Baterie fotogalwaniczne znalazły zastosowanie do zasilania w energię elektryczną obiektów w których niemożliwe jest skorzystanie $\mathrm{z}$ sieci przewodowych np. w domkach letniskowych, na jachtach, w przyczepach kempingowych, przy oświetlaniu: reklam,

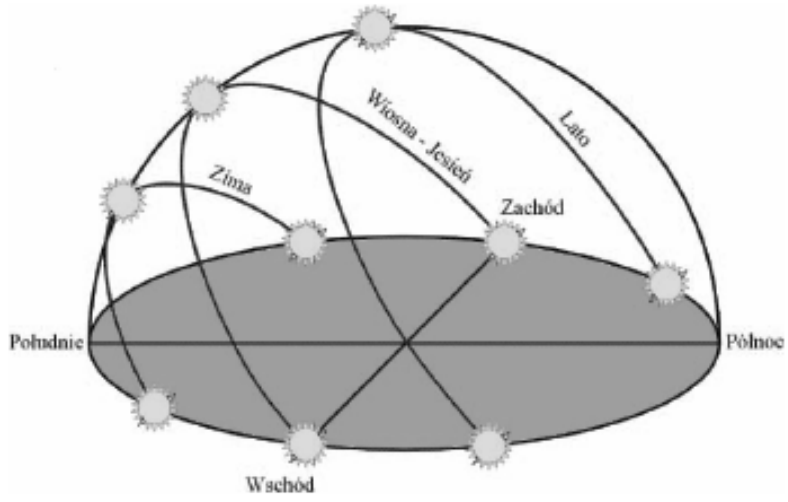

Rys. 1. Położenie słońca na niebie w zależności od pory roku [2]

przejść dla pieszych, bezprzewodowych kamer przemysłowych jak i monitorujących migrację zwierząt. Aktualnie trwaja prace teoretyczne i eksperymentalne dotyczace zastosowania baterii słonecznych do napędu środków transportu. Znane są projekty i wdrożenia zawierające zastosowanie tego źródła energii do napędu hulajnogi [3], pociągów [4, 5], samochodów osobowych [6], autobusów [7], samolotów [8].

W celu jak największej absorpcji energii słonecznej niezbędne jest opracowanie tanich i niezawodnych systemów pozycjonowania baterii względem słońca. $\mathrm{W}$ tym artykule przedstawiona zostanie idea systemu automatycznego ustawiania baterii słonecznych zamontowanych na odbiornikach energii słonecznych.

\section{Propozycja systemu sterowania ogniwami fotogalwanicznymi}

Podstawowym zadaniem projektu jest realizacja układu nadążnego pozycjonowanie baterii fotogalwanicznych względem słońca. Zadanie polegało na opracowaniu koncepcji wykrywania położenia słońca 
oraz odpowiedniego wysterowania silników krokowych w taki sposób, aby płaszczyzna na której znajdują się baterie wraz z czujnikiem różnicowym była ustawiana w kierunku prostopadłym do promieni słonecznych.

Baterie słoneczne najczęściej mają napięcie znamionowe $12 \mathrm{~V}$. Większe wartości napięcia można uzyskać stosując panele generujące moc powyżej 100W. Kierując się kryterium minimaliacji strat energii najbardziej optymalne jest zastosowanie odbiorników o napięciu $12 \mathrm{~V}$. W celu uzyskania zasilania $230 \mathrm{~V}$ niezbędne jest rozbudowanie systemu fotowoltaicznego o przetwornicę prądu 12DC/230AC. Wartość oświetlenia energetycznego zależy głownie od wielkości oświetlanej powierzchni, a wielkość oświetlanej powierzchni zależy od kąta padania promieni słonecznych. Gdy kąt ten wynosi $90^{\circ}$, wiązka promieni pada na najmniejszą powierzchnię. Uzyskuję się wtedy największą koncentrację energii [9].

Zadaniem układu sterowania jest zapewnienie właściwego obrotu powierzchni kolektora w płaszczyźnie poziomej w odpowiednim dla danego terenu zakresie. Dla Polski jest to $270^{\circ}$. System nadążny powinien także umożliwiać swobodę ruchu kolektora w zakresie od 0 do $90^{\circ} \mathrm{w}$ płaszczyźnie pionowej; dla Polski zakres $65^{\circ}$ jest wystarczający ze względu na położenie słońca w dniu 23 czerwca.

Wyróżnia się następujące układy pozycjonowania:

- wertykalny,

- horyzontalny,

- horyzontalno-wertykalny.

W tej pracy założono zbudowanie układu pozycjonowania horyzontalno-wertykalnego, czyli obracającego się w dwóch osiach: poziomej i pionowej.

Schemat układu sterowania wykonano w programie Eagle (rys. 2). Program jest dostępny w tzw. wersji edukacyjnej. Zaletą programu jest bogata biblioteka układów scalonych i elementów elektronicznych. Budowę układu sterowania silnikami krokowymi oparto na mikrokontrolerze A4988 Pololu. Do realizacji zadań $\mathrm{z}$ zakresu sterowania analogowocyfrowego wykorzystano układy z mikrokontrolerem Atmega8 firmy Atmel $\mathrm{z}$ rodziny AVR. Zadania przewidziane do wykonania przez układ sterowania zaprogramowano $\mathrm{w}$ języku C, który podłączono zgodnie z wytycznymi producenta. Układ pomiarowy został zbudowany $\mathrm{z}$ zestawów fotorezystorów wraz $\mathrm{z}$ potencjometrami dopasowującymi. Obsługa optycznego czujnika różnicy natężenia światła odbywa się na 4 wejściach analogowych mikrokontrolera. Dodatkowo wykonano niezależny moduł zasilający odpowiednio filtrowany przez kondensatory z dwoma wyjściami o różnych napięciach 9-12 V dla zasilania silników krokowych, mikrokontrolera Atmega i układów A4988.

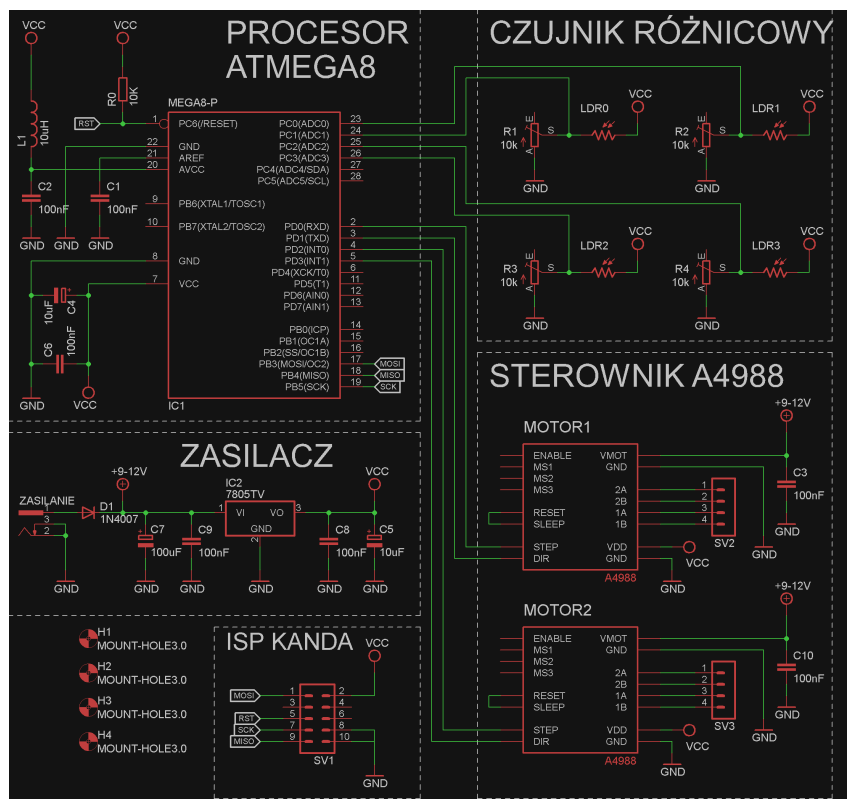

Rys. 2. Schemat połączeń elektrycznych układu sterującego

Program Eagle jest bardzo użyteczny także do projektowania ścieżek drukowanych. Rysunek 3a przedstawia widok ścieżek wraz z rozmieszczonymi elementami układu sterowania, a rysunek 3b przygotowany do wydruku widok połączeń.
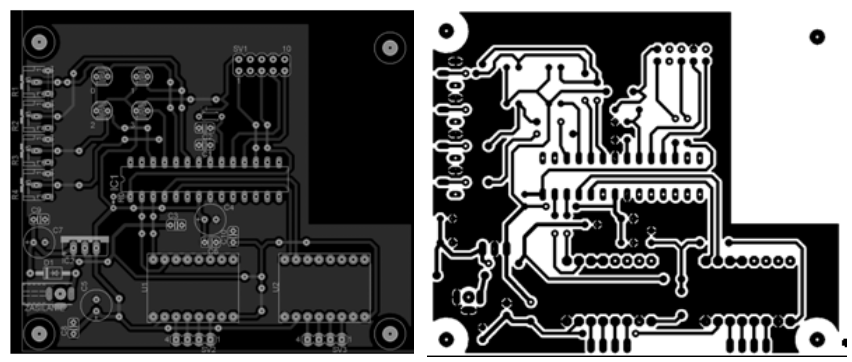

Rys. 3. Schemat połączeń elektrycznych układu sterującego: a) widok połączeń w docelowym rozmieszczeniu elementów, b) widok połączeń przygotowanych do wydruku i naniesienia na laminat

$\mathrm{Na}$ rysunku (rys. 4) przedstawiono model trójwymiarowego różnicowego czujnika natężenia oświetlenia. Zawarto tam cztery fotoelementy przesłonięte nieprzeźroczystą przegrodą. Dzięki tak usytuowanym elementom, można określić pozycję płaszczyzny, na której zamontowane są czujniki w stosunku do źródła światła. Jeżeli źródło światła nie znajduje się w pozycji prostopadłej do płaszczyzny z czujnikami to wtedy przesłony rzucają cień na niektóre czujniki, przez co zmienia się napięcie wyjściowe.
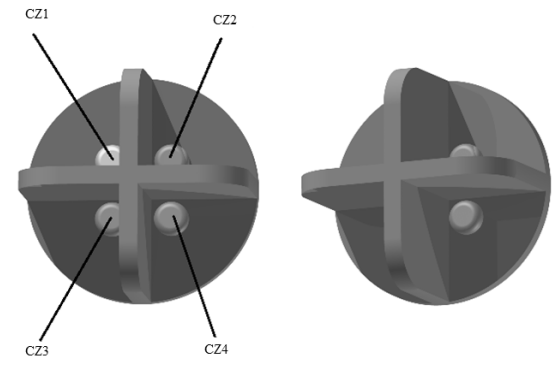

Rys. 4. Model 3D różnicowego czujnika natężenia światła 
Na rysunku 5 przedstawiono zaprojektowany algorytm sterujący. Układ sczytuje wyniki na wejściach analogowych, do których podłączone są fotorezystory, odpowiednio je grupuje i wyznacza średnie arytmetyczne $\mathrm{z}$ poszczególnych par fotoelementów. Zadaniem układu sterowania położeniem kolektorów jest zrównoważenie wartości na odpowiednich parach czujników. Przykładowo, jeżeli wynik średnich z dwóch czujników po lewej stronie (CZ13) plus określona tolerancja $\mathrm{T}$ jest mniejszy od średnich $\mathrm{Z}$ czujników po prawej stronie, silnik krokowy MOTOR 1 odpowiedzialny za ruch w tej płaszczyźnie wykona jeden krok w lewą stronę. Analogicznie wygląda proces dla pozostałych instrukcji warunkowych. Jeżeli średnie są sobie równe silniki zachowują swoją pozycję.

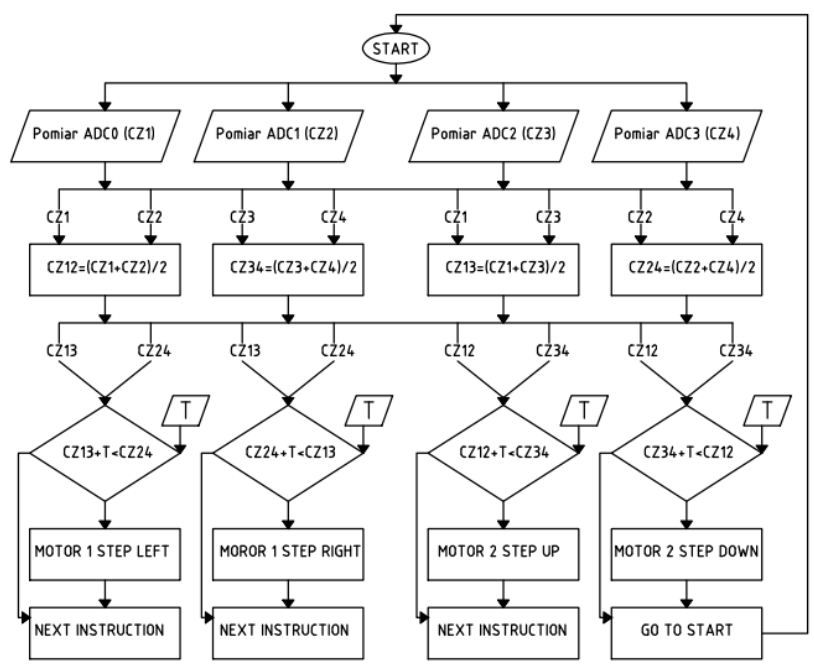

Rys. 5. Algorytm sterujący

Rysunki 6 i 7 przedstawiają prototyp urządzenia wykonanego na płytce stykowej. Rozwiazzanie to umożliwiło przetestowanie działania układu bez konieczności lutowania jego poszczególnych elementów. Krzyżyk na rysunku 7 wskazuje miejsce, w którym powinna znaleźć się przysłona, natomiast okręgi symbolizują fotorezystory.

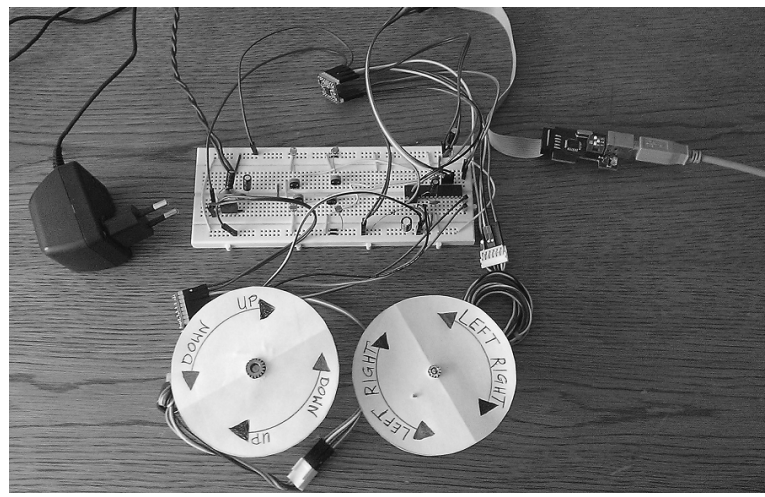

Rys. 6. Prototyp urządzenia wykonany na płytce stykowej

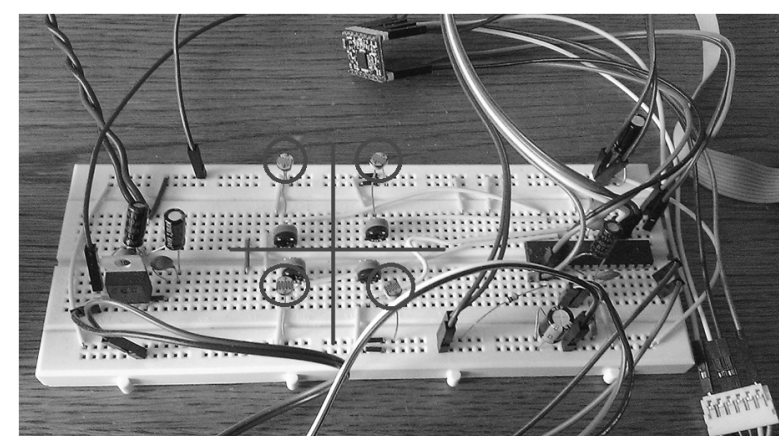

Rys. 7. Widok elementów na płytce stykowej

\section{Podsumowanie}

Dzięki zastosowaniu urządzeń mechatronicznych wykorzystanie energii słonecznej do napędu środków transportu staje się coraz powszechniejsze. Na szczególną uwagę, zasługują rozwiązania dedykowane napędom dużych pojazdów jakimi są lokomotywy i pociagi. Kierując się kryterium ekonomicznym bardzo ważne jest jak największe absorbowanie energii słonecznej i jej magazynowanie. Zaprojektowany i wykonany prototyp urządzenia może z powodzeniem zostać zastosowany do automatycznego dopasowania położenia baterii fotogalwanicznych względem słońca. Przedstawione rozwiązanie cechuje się prostota budowy, niezawodnością oraz niskimi kosztami wykonania.

\section{Literatura}

[1]www.funduszestrukturalne.gov.pl/informator/npr2/progn ozy/zaopatrzenie.pdf

[2] www. ep.com.pl/files/1844.pdf

[3]www.spidersweb.pl/2013/05/hulajnoga-zasilanaenergia-elektryczna-czyli-jak-nie-wydac-ani-groszana-paliwo.html

[4]www.budapesttimes.hu/2013/09/11/first-solar-trainmakes-way-while-sun-shines

[5]www.elektroonline.pl/news/4060,Pociag-napedzanyenergia-sloneczna

[6]www.ekologiczni.pl/2,146,Samochod-na-energiesloneczna

[7]ww.tech.wp.pl/kat,1009779, title,Pierwszy-autobuszasilany-energia-sloneczna

[8] www.eko.v10.pl/Samolot,z,napedem,slonecznym, Solar,Impulse,eksperymentalny, lot, 44687.html

[9] Jajor P. Urbański S. Waluś K. J., Mechatroniczny system pozycjonowania kolektora słonecznego, Zeszyty Naukowe Politechniki Poznańskiej. Maszyny Robocze i Transport,2006, nr 60, s. 67-73. 